\title{
Effect of temperature on life history traits of the predatory thrips, Scolothrips takahashii Priesner (Thysanoptera: Thripidae)
}

\author{
Tetsuo Gotoh, ${ }^{1, *}$ Koichi YAMaguchi, ${ }^{1, \dagger}$ Makiko Fukazawa ${ }^{1}$ and Katsuhiko Mori ${ }^{2, \ddagger}$ \\ ${ }^{1}$ Laboratory of Applied Entomology and Zoology, Faculty of Agriculture, Ibaraki University; Ami, Ibaraki 300-0393, Japan \\ ${ }^{2}$ Research Institute of Japan Plant Protection Association; Ushiku, Ibaraki 300-1212, Japan
}

(Received 1 December 2003; Accepted 21 April 2004)

\begin{abstract}
Scolothrips takahashii is an indigenous thrips in Japan that feeds on many spider mite species. To evaluate whether $S$. takahashii has potential as a biological control agent for spider mites, we investigated the development, survivorship and life-history parameters of $S$. takahashii on a diet of Tetranychus urticae (red form) eggs at different temperatures. More than $74 \%$ of thrips eggs hatched and more than $76 \%$ of newly hatched larvae attained maturity at $15-35^{\circ} \mathrm{C}$. No females laid eggs at 37.5 or $40^{\circ} \mathrm{C}$. The lower threshold temperature for development from egg to oviposition was $11.7^{\circ} \mathrm{C}$ and the thermal constant was calculated as 204.1 degree-days. Based on these data, the maximum number of generations that could complete development in a year under field conditions in Ibaraki, central Japan would be between seven and ten. Mating was unnecessary to induce oviposition but unmated females produced only male progeny. At $25^{\circ} \mathrm{C}$, females laid a mean of 90.5 eggs during a mean oviposition period of 17.8 days. The values for the intrinsic rate of natural increase $\left(r_{\mathrm{m}}\right)$, one important life-history parameter, were 0.113 at $20^{\circ} \mathrm{C}, 0.195$ at $25^{\circ} \mathrm{C}$, and 0.246 at $30^{\circ} \mathrm{C}$. These results suggest $S$. takahashii has considerable potential as a biological control agent against spider mites.
\end{abstract}

Key words: Intrinsic rate of natural increase; lower threshold temperature; predatory thrips; Scolothrips takahashii; Tetranychus urticae

\section{INTRODUCTION}

Spider mites are major agricultural pests in Japan that are difficult to control with agricultural chemicals alone. This is because spider mites can develop resistance to new kinds of acaricides within a few years (Cranham and Helle, 1985; Georghiou, 1990). Therefore, there has been an increasing interest in controlling spider mites with biological control agents, such as predatory thrips, acarophagous ladybugs and predatory mites (Chazeau, 1985; McMurtry and Croft, 1997).

Thrips are phytophagous, pollinophagous, mycetophagous, predacious or general feeders. Only three families (Phlaeothripidae, Aeolothripidae and Thripidae) contain acarophagous thrips (Chazeau, 1985) with various degrees of specialization on mites but all species of Scolothrips appear to be specialized predators of spider mites (Priesner, 1950; Lewis, 1973; Gilstrap and Oatman, 1976; Gilstrap, 1995). Among the species of Scolothrips, the best known and most studied is the North American six-spotted thrips, Scolothrips sexmaculatus (Pergande) (Chazeau, 1985; Gilstrap, 1995). This species is consistently the earliest, most abundant and most significant natural control agent of spider mites on strawberry (Oatman and McMurtry, 1966), rhubarb (Oatman, 1970) and peach (Rice and Jones, 1972).

Scolothrips takahashii Priesner is a native beneficial thrips in Japan and Formosa (Priesner, 1950; Miyazaki and Kudo, 1988). It is common in fields of bean, citrus, pear and tea (Miyazaki and Kudo, 1988), and considered to be an important predator

\footnotetext{
* To whom correspondence should be addressed at: E-mail: gotoh@mx.ibaraki.ac.jp

${ }^{\dagger}$ Present address: Ishihara Sangyo Kaisha, Ltd., 2-3-1 Nishi-Shibukawa, Kusatsu, Shiga 525-0025, Japan

‡ Present address: Kohchi Experiment Station of Japan Plant Protection Association, Noichi, Kohchi 781-5231, Japan DOI: $10.1303 /$ aez.2004.511
} 
of numerous spider mites (Nakagawa, 1993). $S$. takahashii is the earliest and/or most frequent predator of spider mites on tea (Nakagawa, 1993), hydrangea (Gotoh and Gomi, 2000) and Japanese pear (Kishimoto, 2002). Yamasaki et al. (1983) examined the lower threshold temperature for development of S. takahashii and Nakagawa (1993) examined its prey consumption rate, but little else is known about the biology of this species.

Temperature strongly affects the performance of predatory species as biological control agents. Therefore, knowing the temperature requirements of the different stages of a predator life-history can be used to forecast the potential distribution and dynamics of predator populations. Especially the intrinsic rate of natural increase $\left(r_{\mathrm{m}}\right)$ is a key parameter to assess the potential of a predator under laboratory conditions, and temperature is a very important determinant of $r_{\mathrm{m}}$ (Sabelis, 1985b; Roy et al., 2003). In this study, we determined the developmental and reproductive traits of indigenous S. takahashii at different temperatures, and evaluated its potential as a biological control agent of spider mites.

\section{MATERIALS AND METHODS}

To establish a stock culture, S. takahashii were collected from a field population on kudzu vine, Pueraria lobata (Willd.), at Ami $\left(36^{\circ} 01^{\prime} \mathrm{N}-\right.$ $\left.140^{\circ} 11^{\prime} \mathrm{E}\right)$, Ibaraki Prefecture, in the central part of Japan in May 1997. Field-collected thrips were added to the stock culture once a year to maintain genetic diversity. Predatory thrips were maintained on leaves of kudzu vine (June-October) or the lima bean, Phaseolus lunatus L. (November-May), which became infested with an ample number of spider mites. Each leaf was placed on agar $(0.5 \%$, $10 \mathrm{~mm}$ thick) including $1 \%$ gentian violet in a plastic cup $(80 \mathrm{~mm} \phi$ top $\times 55 \mathrm{~mm} \phi$ bottom $\times 60 \mathrm{~mm}$ high) with a lid at $25 \pm 1{ }^{\circ} \mathrm{C}$ and a $16 \mathrm{~L}: 8 \mathrm{D}$ photoperiod. A 30-mm-diameter hole was cut in the lid of each cup and covered with fine nylon mesh to allow ventilation. To provide food for the thrips, the two-spotted spider mite, Tetranychus urticae Koch (red form), was cultured on leaf discs (ca. $12 \mathrm{~cm}^{2}$ ) of kudzu vine or lima bean placed on a water-saturated polyurethane mat in a Petri dish $(9 \mathrm{~cm} \phi)$. When the mite densities on a leaf disc reached an acceptable level, the leaf disc was placed in a cup. For the experiments, S. takahashii was allowed to feed on only mite eggs. To obtain prey eggs for S. takahashii, 20-40 adult females of T. urticae from a stock culture were introduced onto a clean leaf disc (ca. $12 \mathrm{~cm}^{2}$ ) of lima bean and allowed to lay eggs (ca. 300-500 eggs) for $48 \mathrm{~h}$ at $25^{\circ} \mathrm{C}$ and $16 \mathrm{~L}: 8 \mathrm{D}$, and then the females were removed. Each lima bean leaf with mite eggs was placed on agar in a plastic cup, referred to as a leaf cup in this paper.

Scolothrips takahashii adults with parallel wings were examined under a stereomicroscope to determine sex after the procedures of Lewis (1973). Males (body length, $1.1 \pm 0.09 \mathrm{~mm}$ (mean \pm S.D.), $N=100)$ are always smaller than females $(1.4 \pm 0.11, N=100 ; p<0.001, Z=-11.838$, MannWhitney $U$-test). The terminal segments in males are bluntly rounded at the tip. Females have a conspicuous brownish ovipositor, which usually lies retracted beneath a gradually tapered abdomen.

To determine the effect of temperature on survival, development and fecundity of $S$. takahashii, an inseminated adult female was placed in a leaf cup and allowed to lay eggs for $24 \mathrm{~h}$ at eleven constant temperatures from 15 to $40^{\circ} \mathrm{C}$ at $2.5^{\circ} \mathrm{C}$ intervals under a long-day photoperiod (16L : 8D). Females laid their eggs singly in an incision made in the leaf tissue with their ovipositor. Eggs were identified as whitish ellipses floating in a greenish background when viewed with a transmitted light under a stereomicroscope. The eggs on a leaf disc were counted every day to determine the time to hatching and the percent hatched. Newly hatched 1 st instar larvae were individually placed in a leaf cup after hatching. The instar stage was recorded daily. The leaf cups were renewed every two days until pupation. When a female adult emerged, one adult male was introduced into the leaf cup for mating. Two days later, the male was removed and females were observed daily to assess the date of first oviposition. At 20,25 and $30^{\circ} \mathrm{C}$, the number of eggs laid by predatory females was counted daily until the females died. The predatory female was transferred to a new leaf cup every two days to ensure she ate only mite eggs and not hatched mite eggs (i.e., mite larvae).

The intrinsic rate of natural increase, $r_{\mathrm{m}}$, was estimated from the life-fecundity table according to the equation given by Birch (1948): $\sum e^{-r_{\mathrm{m}} x} l_{x} m_{x}=1$, where $x$ is age in days, $l_{x}$ is the age- 
specific survival rate ((proportion of females alive at age $x) \times(\%$ egg hatch $))$, and $m_{x}$ is oviposition rate at age $x$ ((age-specific oviposition) $\times($ proportion of females)) (Sabelis, 1985a, 1991; Gotoh, 1986). The Jackknife procedure was used to estimate a standard error for the $r_{\mathrm{m}}$-values (Meyer et al., 1986). For the comparison of the different $r_{\mathrm{m}}$ values, analysis of variance (ANOVA) and Tukey's test were used (SPSS, 2002). The net reproductive rate, $R_{0}$, is given by $R_{0}=\sum l_{x} m_{x}$, the mean generation time, $T$, in days, is given by $T=\ln R_{0} / r_{\mathrm{m}}$, the finite rate of increase, $\lambda$, is given by $\lambda=e^{r_{\mathrm{m}}}$, and the doubling time, $D$, is given by $D=\ln 2 / r_{\mathrm{m}}$. To determine hatchability and the proportion of females that appeared in the $l_{x}$ and $m_{x}$ formulae, females were placed in leaf cups and allowed to lay eggs for five days after starting oviposition at 20,25 and $30^{\circ} \mathrm{C}$.

Fisher's exact probability test $(p<0.05)$ was used for all possible pairwise comparisons of eclosion rates of eggs and survival rates at different temperatures. The type-I error was corrected by the Bonferroni method (Sokal and Rohlf, 1995; Nagata and Yoshida, 1997). ANOVA was used to compare the influence of temperature on the number of eggs laid during the first five days of the oviposition period and their hatchability, survival rate and female ratio. ANOVA was also used to compare the influence of temperature on developmental time, oviposition rate, durations of adult female reproductive stages and parameters of population increase. Means were compared among temperatures using the Tukey's test (SPSS, 2002). The logarithmic transferred values or arcsine-root transferred values were used for analysis (Sokal and Rohlf, 1995; Yamamura, 2002). The threshold temperature for the various stages were estimated by linear regression using the values obtained at adequate temperatures and excluding the values at temperatures that resulted in significantly higher mortalities (LopezArroyo et al., 1999; Broufas and Koveos, 2000). The lower threshold temperatures $\left(t_{0}\right)$ were extrapolated from the linear portion of each curve towards the $x$-axis. The thermal constants (degreedays, $K$ ) were calculated as 1 /slope of the temperature-developmental rate curve. Standard errors of $t_{0}$ and $K$ were computed as in Campbell et al. (1974).
Table 1. Hatchability and survival rate in immature stages of the predatory thrips, Scolothrips takahashii, at nine constant temperatures under a $16 \mathrm{~L}: 8 \mathrm{D}$ photoperiod

\begin{tabular}{ccccc}
\hline $\begin{array}{c}\text { Temp. } \\
\left({ }^{\circ} \mathrm{C}\right)\end{array}$ & $\begin{array}{c}\text { No. of eggs } \\
\text { tested }\end{array}$ & $\begin{array}{c}\text { Eclosion of } \\
\text { eggs }(\%)^{\mathrm{a}}\end{array}$ & $\begin{array}{c}\text { No. of larvae } \\
\text { introduced }\end{array}$ & \% Maturity \\
\hline 15.0 & 87 & $81.6 \mathrm{ab}$ & 70 & $92.9 \mathrm{ab}$ \\
17.5 & 371 & $84.1 \mathrm{ab}$ & 65 & $96.9 \mathrm{a}$ \\
20.0 & 110 & $92.9 \mathrm{a}$ & 47 & $93.6 \mathrm{a}$ \\
22.5 & 67 & $94.0 \mathrm{a}$ & 70 & $92.9 \mathrm{ab}$ \\
25.0 & 72 & $91.7 \mathrm{a}$ & 69 & $97.1 \mathrm{a}$ \\
27.5 & 59 & $94.9 \mathrm{a}$ & 100 & $95.0 \mathrm{a}$ \\
30.0 & 42 & $88.1 \mathrm{ab}$ & 55 & $98.2 \mathrm{a}$ \\
32.5 & 76 & $77.6 \mathrm{ab}$ & 59 & $76.3 \mathrm{~b}$ \\
35.0 & 121 & $74.4 \mathrm{~b}$ & 49 & $81.6 \mathrm{ab}$
\end{tabular}

${ }^{a}$ Values followed by the same letters were not significantly different at the 5\% level (Fisher's exact probability test with the Bonferroni method).

\section{RESULTS}

\section{Development}

At each temperature between $15^{\circ} \mathrm{C}$ and $32.5^{\circ} \mathrm{C}$, hatchability was more than $77 \%$ (range: $77.6-$ $94.9 \%$ ) and there was no significant difference among temperatures (Table 1; Fisher's exact probability test with the Bonferroni method, $p>0.05$ ). At $35^{\circ} \mathrm{C}$, hatchability was slightly lower than at $20-27.5^{\circ} \mathrm{C}$. Survival rate from larva to adult was more than $76 \%$ at all temperatures. For eggs that were obtained at $25^{\circ} \mathrm{C}$ and incubated at $37.5^{\circ} \mathrm{C}$, about half $(53.2 \%, N=218)$ hatched and about half of the resulting larvae $(57.1 \%, N=42)$ attained maturity. However, at $40^{\circ} \mathrm{C}$, no hatching $(N=107)$ was observed, even in eggs that were laid at $25^{\circ} \mathrm{C}$.

Developmental time in females and males decreased as the temperature increased from 15 to $30^{\circ} \mathrm{C}$ (Table $2 ; p<0.05$, Tukey's test). The total developmental time from egg to adult was 49.5 days for females and 48.2 days for males at $15^{\circ} \mathrm{C}$, and 10.3 days and 9.9 days, respectively, at $30.0^{\circ} \mathrm{C}$. Developmental time at 32.5 and $35^{\circ} \mathrm{C}$ were not significantly different in both sexes $(p>0.05$, Tukey's test). At all temperatures between 15 and $35^{\circ} \mathrm{C}$, all emerged females laid eggs within $0.5-8$ days $(p<0.05$, Tukey's test).

Developmental rate was significantly related to temperature between 15 and $35^{\circ} \mathrm{C}$ for all developmental stages. The prepupal stage had the lowest temperature threshold, $10.4^{\circ} \mathrm{C}$, while the preoviposition period had the highest temperature threshold, 
Table 2. Developmental duration and preoviposition period for S. takahashii at nine constant temperatures under a $16 \mathrm{~L}: 8 \mathrm{D}$ photoperiod

\begin{tabular}{|c|c|c|c|c|c|c|c|c|}
\hline \multirow{2}{*}{$\begin{array}{l}\text { Temp. } \\
\left({ }^{\circ} \mathrm{C}\right)\end{array}$} & \multirow[b]{2}{*}{$N^{\mathrm{a}}$} & \multicolumn{5}{|c|}{ Developmental duration in days (Mean \pm S.E.) } & \multirow[b]{2}{*}{ Total $^{\mathrm{b}}$} & \multirow{2}{*}{$\begin{array}{l}\text { Preoviposition } \\
\text { period }^{\mathrm{b}}\end{array}$} \\
\hline & & Egg & $\begin{array}{l}\text { 1st instar } \\
\text { larva }\end{array}$ & $\begin{array}{l}\text { 2nd instar } \\
\text { larva }\end{array}$ & Prepupa & Pupa & & \\
\hline \multicolumn{9}{|l|}{ Females } \\
\hline 15.0 & 33 & $23.8 \pm 0.26$ & $6.2 \pm 0.26$ & $9.4 \pm 0.43$ & $3.2 \pm 0.12$ & $6.9 \pm 0.14$ & $49.5 \pm 0.45 \mathrm{~h}$ & $7.8 \pm 0.54 \mathrm{f}$ \\
\hline 17.5 & 62 & $15.5 \pm 0.18$ & $4.0 \pm 0.09$ & $4.9 \pm 0.11$ & $2.0 \pm 0.04$ & $4.0 \pm 0.06$ & $30.4 \pm 0.19 \mathrm{~g}$ & $3.7 \pm 0.14 \mathrm{e}$ \\
\hline 20.0 & 41 & $12.4 \pm 0.10$ & $2.3 \pm 0.08$ & $4.9 \pm 0.20$ & $1.8 \pm 0.07$ & $3.0 \pm 0.08$ & $24.4 \pm 0.23 \mathrm{f}$ & $3.8 \pm 0.33 \mathrm{e}$ \\
\hline 22.5 & 19 & $8.6 \pm 0.11$ & $2.3 \pm 0.11$ & $2.5 \pm 0.12$ & $1.2 \pm 0.10$ & $2.2 \pm 0.09$ & $16.8 \pm 0.14 \mathrm{e}$ & $2.1 \pm 0.11 \mathrm{~d}$ \\
\hline 25.0 & 32 & $6.7 \pm 0.11$ & $1.8 \pm 0.07$ & $2.2 \pm 0.08$ & $1.0 \pm 0.03$ & $1.7 \pm 0.09$ & $13.3 \pm 0.10 \mathrm{~d}$ & $1.7 \pm 0.10 \mathrm{~d}$ \\
\hline 27.5 & 28 & $5.9 \pm 0.12$ & $1.4 \pm 0.10$ & $1.8 \pm 0.12$ & $0.8 \pm 0.08$ & $1.5 \pm 0.10$ & $11.4 \pm 0.14 \mathrm{c}$ & $1.6 \pm 0.13 \mathrm{~cd}$ \\
\hline 30.0 & 18 & $5.4 \pm 0.14$ & $1.3 \pm 0.11$ & $1.6 \pm 0.12$ & $0.7 \pm 0.11$ & $1.4 \pm 0.12$ & $10.3 \pm 0.14 b$ & $1.1 \pm 0.06 \mathrm{bc}$ \\
\hline 32.5 & 23 & $4.6 \pm 0.10$ & $1.2 \pm 0.09$ & $1.3 \pm 0.10$ & $0.5 \pm 0.11$ & $1.0 \pm 0.00$ & $8.6 \pm 0.10 \mathrm{a}$ & $1.0 \pm 0.04 \mathrm{~b}$ \\
\hline 35.0 & 14 & $4.3 \pm 0.16$ & $1.0 \pm 0.00$ & $0.8 \pm 0.11$ & $0.8 \pm 0.11$ & $1.0 \pm 0.00$ & $8.2 \pm 0.24 \mathrm{a}$ & $0.6 \pm 0.13 \mathrm{a}$ \\
\hline$F$ & & & & & & & $3,265.947$ & 86.927 \\
\hline df & & & & & & & 8,261 & 8,261 \\
\hline$p$ & & & & & & & $<0.0001$ & $<0.0001$ \\
\hline \multicolumn{9}{|l|}{ Males } \\
\hline 15.0 & 28 & $23.9 \pm 0.47$ & $7.4 \pm 0.24$ & $7.1 \pm 0.34$ & $3.4 \pm 0.13$ & $6.4 \pm 0.16$ & $48.2 \pm 0.49 \mathrm{~h}$ & \\
\hline 17.5 & 47 & $15.6 \pm 0.19$ & $4.1 \pm 0.16$ & $4.6 \pm 0.18$ & $2.1 \pm 0.09$ & $3.8 \pm 0.10$ & $30.2 \pm 0.30 \mathrm{~g}$ & \\
\hline 20.0 & 35 & $12.3 \pm 0.15$ & $3.5 \pm 0.18$ & $3.7 \pm 0.18$ & $1.6 \pm 0.09$ & $2.9 \pm 0.12$ & $23.9 \pm 0.26 \mathrm{f}$ & \\
\hline 22.5 & 25 & $8.8 \pm 0.18$ & $2.5 \pm 0.10$ & $2.2 \pm 0.08$ & $1.1 \pm 0.06$ & $2.0 \pm 0.04$ & $16.6 \pm 0.17 \mathrm{e}$ & \\
\hline 25.0 & 21 & $6.6 \pm 0.13$ & $1.8 \pm 0.13$ & $2.2 \pm 0.12$ & $0.9 \pm 0.07$ & $1.6 \pm 0.11$ & $13.1 \pm 0.17 \mathrm{~d}$ & \\
\hline 27.5 & 24 & $5.7 \pm 0.09$ & $1.5 \pm 0.10$ & $1.6 \pm 0.10$ & $0.8 \pm 0.08$ & $1.3 \pm 0.10$ & $11.0 \pm 0.12 \mathrm{c}$ & \\
\hline 30.0 & 16 & $5.4 \pm 0.13$ & $1.3 \pm 0.12$ & $1.4 \pm 0.13$ & $0.7 \pm 0.12$ & $1.1 \pm 0.09$ & $9.9 \pm 0.17 b$ & \\
\hline 32.5 & 22 & $4.5 \pm 0.11$ & $1.2 \pm 0.08$ & $1.1 \pm 0.10$ & $0.5 \pm 0.11$ & $1.0 \pm 0.00$ & $8.5 \pm 0.11 \mathrm{a}$ & \\
\hline 35.0 & 16 & $4.3 \pm 0.11$ & $1.1 \pm 0.09$ & $0.6 \pm 0.13$ & $0.6 \pm 0.13$ & $1.1 \pm 0.06$ & $8.3 \pm 0.24 \mathrm{a}$ & \\
\hline$F$ & & & & & & & $2,253.486$ & \\
\hline df & & & & & & & 8,225 & \\
\hline$p$ & & & & & & & $<0.0001$ & \\
\hline
\end{tabular}

${ }^{\mathrm{a}}$ Number of individuals tested.

${ }^{b}$ Values within the same column and/or sex followed by the same letter were not significantly different at the 5\% level (Tukey's test).

$14.9^{\circ} \mathrm{C}$ (Table 3 ). The thermal constant from egg to adult was 188.7 DD for both females and males (Table 3).

The reproductive period for $S$. takahashii was assumed to last from May to November, the period when insect predators had been observed in the field of Ibaraki (T. G., personal observation). When the total degree-days (1,538-2,114 DD) accumulated above a lower threshold temperature of $11.7^{\circ} \mathrm{C}$ (egg-to-egg) for the past ten years (1993-2002) were divided by a thermal constant of 204.1 DD for egg-to-egg, the maximum number of generations that $S$. takahashii could complete in each of these 10 years ranged between seven and ten generations.

The number of eggs laid during the first five days of the oviposition period increased significantly as temperature increased (Table $4, p<0.05$, Tukey's test). Eclosion of eggs, survival rate in immature stages and sex ratio (proportion of daughters) were not significantly affected by temperature in this range ( $p>0.05$, ANOVA).

Virgin females of $S$. takahashii produced only male progeny: the number of eggs laid per female during the first five days of the oviposition period, the number of larvae hatched and the number of males emerged $(N=13)$ were $26.2 \pm 1.29$ (mean \pm S.E.), $23.6 \pm 0.28$ and $21.7 \pm 1.24$, respectively. On the other hand, as shown in Table 4 fertilized females produced mostly females with some males from non-inseminated eggs. This shows that this species is arrhenotokous, i.e., females are 
Table 3. Regression equation, lower threshold temperatures of development and thermal constants for S. takahashii

\begin{tabular}{|c|c|c|c|c|}
\hline Stage & Regression equation $^{\mathrm{a}}$ & $r^{2}$ & $\begin{array}{c}\text { Lower } \\
\text { threshold } \\
\left(t_{0},{ }^{\circ} \mathrm{C}\right)^{\mathrm{c}}\end{array}$ & $\begin{array}{c}\text { Thermal } \\
\text { constant }(K) \\
\text { (degree-days) }\end{array}$ \\
\hline \multicolumn{5}{|l|}{ Female } \\
\hline Egg & $y=-0.1075+0.0099 x$ & $0.9925^{* * * b}$ & $10.9 \pm 0.51$ & $101.0 \pm 3.33$ \\
\hline 1 st instar larva & $y=-0.4522+0.0409 x$ & $0.9831 * * *$ & $11.1 \pm 0.76$ & $24.5 \pm 1.21$ \\
\hline 2nd instar larva & $y=-0.5142+0.0394 x$ & $0.9805^{* * *}$ & $13.1 \pm 0.72$ & $25.4 \pm 1.36$ \\
\hline Prepupa & $y=-0.7210+0.0694 x$ & $0.8014 * *$ & $10.4 \pm 3.01$ & $14.4 \pm 2.71$ \\
\hline Pupa & $y=-0.5349+0.0443 x$ & $0.9776^{* * *}$ & $12.1 \pm 0.83$ & $22.6 \pm 1.29$ \\
\hline Egg-adult & $y=-0.0605+0.0053 x$ & $0.9935 * * *$ & $11.4 \pm 0.46$ & $188.7 \pm 5.73$ \\
\hline Preoviposition & $y=-0.9721+0.0653 x$ & $0.8809^{* * *}$ & $14.9 \pm 1.67$ & $15.3 \pm 2.13$ \\
\hline Egg-adult oviposition & $y=-0.0573+0.0049 x$ & $0.9968 * * *$ & $11.7 \pm 0.31$ & $204.1 \pm 4.36$ \\
\hline \multicolumn{5}{|l|}{ Male } \\
\hline Egg & $y=-0.1103+0.0100 x$ & $0.9883 * * *$ & $11.0 \pm 0.63$ & $100.0 \pm 4.08$ \\
\hline 1st instar larva & $y=-0.4831+0.0407 x$ & $0.9891 * * *$ & $11.9 \pm 0.58$ & $24.6 \pm 0.97$ \\
\hline 2nd instar larva & $y=-0.4351+0.0376 x$ & $0.9377 * * *$ & $11.6 \pm 1.45$ & $26.6 \pm 2.59$ \\
\hline Prepupa & $y=-0.9171+0.0801 x$ & $0.9389 * * *$ & $11.3 \pm 1.45$ & $12.9 \pm 1.20$ \\
\hline Pupa & $y=-0.4948+0.0441 x$ & $0.9545 * * *$ & $11.2 \pm 1.26$ & $22.7 \pm 1.87$ \\
\hline Egg-adult & $y=-0.0598+0.0053 x$ & $0.9914 * * *$ & $11.3 \pm 0.48$ & $188.7 \pm 6.20$ \\
\hline
\end{tabular}

${ }^{a}$ Regression equations were calculated based on the values obtained from 15.0 to $35.0^{\circ} \mathrm{C}$.

${ }^{\mathrm{b}}$ Regression analysis. ${ }^{* *}: p<0.01 ; * *: p<0.001$.

${ }^{c}$ Mean \pm S.E. Standard errors were calculated according to the equations given by Campbell et al. (1974).

Table 4. Number of eggs laid during the first five days of the oviposition period, eclosion of eggs, survival rate of immature stages and the proportion of females reaching adulthood in S. takahashii at three constant temperatures under a $16 \mathrm{~L}: 8 \mathrm{D}$ photoperiod

\begin{tabular}{cccccc}
\hline Temp. $\left({ }^{\circ} \mathrm{C}\right)$ & $N^{\mathrm{a}}$ & $\begin{array}{c}\text { No. of } \\
\text { eggs/female }\end{array}$ & $\begin{array}{c}\text { Eclosion of eggs } \\
(\%)^{\mathrm{b}}\end{array}$ & $\begin{array}{c}\text { Survival rate in } \\
\text { immatures }(\%)^{\mathrm{b}}\end{array}$ & $\begin{array}{c}\text { Proportion of } \\
\text { females }(\%)^{\mathrm{b}}\end{array}$ \\
\hline 20.0 & 11 & $10.9 \pm 1.04 \mathrm{a}$ & $90.8 \pm 2.12 \mathrm{a}$ & $90.2 \pm 2.16 \mathrm{a}$ & $78.0 \pm 1.98 \mathrm{a}$ \\
25.0 & 12 & $26.5 \pm 2.32 \mathrm{~b}$ & $91.1 \pm 2.06 \mathrm{a}$ & $93.3 \pm 1.19 \mathrm{a}$ & $75.8 \pm 1.74 \mathrm{a}$ \\
30.0 & 12 & $36.0 \pm 1.85 \mathrm{c}$ & $90.4 \pm 2.38 \mathrm{a}$ & $94.5 \pm 1.78 \mathrm{a}$ & $80.3 \pm 2.13 \mathrm{a}$ \\
$F$ & & 54.750 & 0.024 & 1.627 & 1.349 \\
$\mathrm{df}$ & 2,32 & 2,32 & 2,32 & 2,32 \\
$p$ & $<0.0001$ & 0.976 & 0.212 & 0.274 \\
\hline
\end{tabular}

${ }^{\text {a }}$ Number of females tested.

${ }^{\mathrm{b}}$ Data were analysed using ANOVA and are shown as mean \pm S.E. Values within columns followed by the same letters were not significantly different at the $5 \%$ level (Tukey's test).

diploid but males develop from unfertilized haploid eggs.

\section{Reproduction}

The total number of eggs laid per female was not significantly different at 20,25 and $30^{\circ} \mathrm{C}$ (Table 5; $p=0.056$, ANOVA). As the temperature increased, the daily egg production increased, but the preoviposition period, oviposition period and total adult longevity became shorter (Table 5, $p<0.0001$, ANOVA). The total adult longevity was shortest at $30^{\circ} \mathrm{C}$.

The $l_{x}$ (age-specific survival rate) started to drop at earlier ages as the temperature increased from 20 to $30^{\circ} \mathrm{C}$ (Fig. 1, dotted lines). The $m_{x}$ (age-specific fecundity rate) peaked at earlier ages and the width of the peak, i.e., the oviposition period, became narrower as the temperature increased (dashed lines). At 20,25 and $30^{\circ} \mathrm{C}$, age at the first oviposition was 24, 15 and 12 days, respectively. Daily 
Table 5. Oviposition rates and various durations (in days) of female adults of S. takahashii at three constant temperatures under a $16 \mathrm{~L}: 8 \mathrm{D}$ photoperiod

\begin{tabular}{|c|c|c|c|c|c|c|}
\hline \multirow{2}{*}{ Parameter } & \multicolumn{3}{|c|}{ Temperature $\left({ }^{\circ} \mathrm{C}\right)$} & \multirow{2}{*}{$F$} & \multirow{2}{*}{$\mathrm{df}$} & \multirow{2}{*}{$p$} \\
\hline & $20.0(N=15)^{\mathrm{a}}$ & $25.0(N=20)^{\mathrm{a}}$ & $30.0(N=17)^{\mathrm{a}}$ & & & \\
\hline $\begin{array}{l}\text { No. of eggs/female } \\
\text { (Maximum fecundity) }\end{array}$ & $\begin{array}{r}62.2 \pm 6.71 \\
(104)\end{array}$ & $\begin{array}{r}90.5 \pm 9.36 \\
(164)\end{array}$ & $\begin{array}{r}66.4 \pm 4.44 \\
(114)\end{array}$ & 3.054 & 2,49 & 0.056 \\
\hline No. of eggs/female/day & $2.7 \pm 0.13 \mathrm{c}$ & $5.1 \pm 0.43 b$ & $6.5 \pm 0.37 \mathrm{a}$ & 36.990 & 2,49 & $<0.0001$ \\
\hline Preoviposition period & $2.9 \pm 0.19 \mathrm{a}$ & $1.9 \pm 0.16 \mathrm{~b}$ & $1.1 \pm 0.06 \mathrm{c}$ & 39.757 & 2,49 & $<0.0001$ \\
\hline Oviposition period & $23.4 \pm 2.44 \mathrm{a}$ & $17.8 \pm 1.31 \mathrm{a}$ & $10.4 \pm 0.61 \mathrm{~b}$ & 24.303 & 2,49 & $<0.0001$ \\
\hline Postoviposition period & $3.9 \pm 0.82 \mathrm{a}$ & $2.8 \pm 0.52 \mathrm{a}$ & $0.7 \pm 0.32 \mathrm{~b}$ & 10.721 & 2,49 & $<0.0001$ \\
\hline Total adult longevity & $30.2 \pm 2.70 \mathrm{a}$ & $22.4 \pm 1.48 \mathrm{~b}$ & $12.1 \pm 0.76 \mathrm{c}$ & 36.102 & 2,49 & $<0.0001$ \\
\hline
\end{tabular}

${ }^{\text {a }}$ Number of females tested. Data were analysed using ANOVA and are shown as mean \pm S.E. Values in rows followed by the same letters were not significantly different at the $5 \%$ level (Tukey's test).
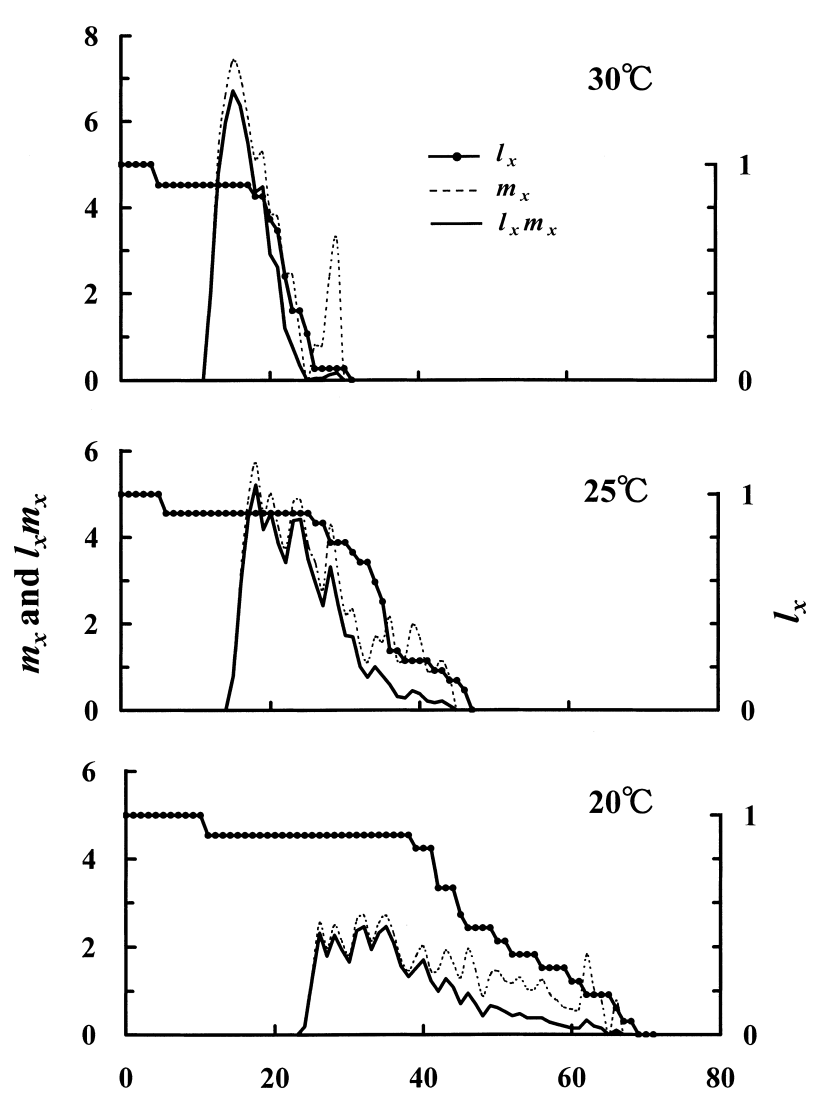

Age in days

Fig. 1. Age-specific survival rate $\left(l_{x}\right)$, age-specific fecundity rate $\left(m_{x}\right)$ and $l_{x} m_{x}$ curves in $S$. takahashii. $l_{x}=($ eclosion of eggs $) \times($ proportion of females alive at age $x) . m_{x}=$ (proportion of females $) \times($ age-specific oviposition $)$. egg production reached a peak of 3.5 eggs on day 32 at $20^{\circ} \mathrm{C}, 7.6$ eggs on day 18 at $25^{\circ} \mathrm{C}$ and 9.2 eggs on day 15 at $30^{\circ} \mathrm{C}$. Female adults started to die on day 39, 26 and 18 at the respective temperatures. The $l_{x} m_{x}$ curve, which is the product of $l_{x}$ and $m_{x}$, was the same as the $m_{x}$ curve except with slightly lower values (solid lines).

The net reproductive rate $\left(R_{0}\right)$ was highest at $25^{\circ} \mathrm{C}$ followed by $30^{\circ} \mathrm{C}$ (Table 6 ). The intrinsic rate of natural increase $\left(r_{\mathrm{m}}\right.$, day $\left.^{-1}\right)$ and finite rate of increase $(\lambda)$ increased with temperature, and the $r_{\mathrm{m}}$ value reached a peak of 0.246 day $^{-1}$ at $30^{\circ} \mathrm{C}$. Mean generation time ( $T$, in days) and doubling time $(D)$ decreased with increasing temperature.

\section{DISCUSSION}

The predatory thrips, S. takahashii, developed successfully over a range of 15 to $35^{\circ} \mathrm{C}$ with a low mortality from $1.8 \%\left(30^{\circ} \mathrm{C}\right)$ to $23.7 \%\left(32.5^{\circ} \mathrm{C}\right)$, but at $37.5^{\circ} \mathrm{C}$ no females oviposited. In a study of $S$. sexmaculatus (Gilstrap and Oatman, 1976), no eggs hatched at $18.3^{\circ} \mathrm{C}$ but most larvae $(90.6 \%)$ were able to reach maturity at this temperature, and larval survivorship did not decrease even at $40^{\circ} \mathrm{C}$. Developmental time (13.3 days) of $S$. takahashii at $25^{\circ} \mathrm{C}$ was shorter than that of $S$. sexmaculatus (16.1 days, Gilstrap and Oatman, 1976; 15.7 days, Coville and Allen, 1977). The lower threshold temperature $\left(11.4^{\circ} \mathrm{C}\right)$ of $S$. takahashii is slightly lower than the previously reported value for $S$. takahashii $\left(15.2^{\circ} \mathrm{C}\right.$, Yamasaki et al., 1983) and that for $S$. sexmaculatus $\left(14.0^{\circ} \mathrm{C}\right.$, Gilstrap and Oatman, 1976; $13.1^{\circ} \mathrm{C}$, Coville and Allen, 1977). The thermal 
Table 6. Parameters of population increase in S. takahashii at three constant temperatures under a $16 \mathrm{~L}: 8 \mathrm{D}$ photoperiod

\begin{tabular}{|c|c|c|c|c|c|c|}
\hline $\begin{array}{l}\text { Temp. } \\
\left({ }^{\circ} \mathrm{C}\right)\end{array}$ & $N^{\mathrm{a}}$ & $\begin{array}{l}\text { Net } \\
\text { reproductive } \\
\text { rate }\left(R_{0}\right)\end{array}$ & $\begin{array}{l}\text { Intrinsic rate of } \\
\text { natural increase } \\
\qquad\left(r_{\mathrm{m}}, \text { day }^{-1}\right)\end{array}$ & $\begin{array}{c}\text { Mean } \\
\text { generation time } \\
\text { in days }(T)\end{array}$ & $\begin{array}{l}\text { Finite rate of } \\
\text { increase }(\lambda)\end{array}$ & $\begin{array}{l}\text { Doubling time } \\
\text { (D) }\end{array}$ \\
\hline 20 & 15 & 44.053 & $0.113 \pm 0.0016 \mathrm{a}$ & 33.650 & 1.119 & 6.161 \\
\hline 25 & 20 & 62.425 & $0.195 \pm 0.0045 b$ & 21.174 & 1.216 & 3.550 \\
\hline 30 & 17 & 45.861 & $0.246 \pm 0.0052 \mathrm{c}$ & 15.510 & 1.279 & 2.813 \\
\hline$F$ & & & 197.88 & & & \\
\hline df & & & 2,49 & & & \\
\hline$p$ & & & $<0.0001$ & & & \\
\hline
\end{tabular}

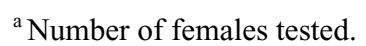

${ }^{b}$ Data were analysed using ANOVA and are shown as mean \pm S.E. Values within columns followed by the different letters were significantly different at the $5 \%$ level (Tukey's test).

constant (188.7 DD) of S. takahashii is higher than the previously reported value for $S$. takahashii (144.7 DD, Yamasaki et al., 1983), but is slightly lower than that of S. sexmaculatus (209.9 DD, Gilstrap and Oatman, 1976; 192.6 DD, Coville and Allen, 1977). These results suggest that S. takahashii as well as $S$. sexmaculatus has potential to develop over a relatively wide range of temperatures.

Although a few studies have examined the lifehistory traits of thrips, we are aware of only two studies that have examined the life-history of predatory thrips ( $S$. sexmaculatus) (Gilstrap and Oatman, 1976; Coville and Allen, 1977). The $r_{\mathrm{m}}{ }^{-}$ value $\left(0.195\right.$ at $\left.25^{\circ} \mathrm{C}\right)$ of $S$. takahashii was higher than the values reported for $S$. sexmaculatus. At around $25^{\circ} \mathrm{C}$, the $r_{\mathrm{m}}$-value of $S$. sexmaculatus was 0.155 (Gilstrap and Oatman, 1976) and 0.180 (Coville and Allen, 1977). However, the net reproductive rate $\left(R_{0}=62.4\right)$ of $S$. takahashii was lower than that of $S$. sexmaculatus (192.1, Gilstrap and Oatman (1976); 93.0, Coville and Allen (1977)). The mean generation time, $T$ (21.2), of $S$. takahashii was shorter than the values for $S$. sexmaculatus (33.9, Gilstrap and Oatman (1976); 25.2, Coville and Allen (1977)). Thus, the life history parameters of $S$. takahashii are slightly higher than or almost equal to those of $S$. sexmaculatus, suggesting that $S$. takahashii has similar potential as $S$. sexmaculatus to control spider mites.

In Central Japan (Kanto plain), S. takahashii is well synchronized with spider mites such as T. urticae and T. kanzawai Kishida in early season emergence (Kishimoto, 2002), suggesting the predatory thrips, S. takahashii, can act in environ- ments where target spider mite densities are low. This is because the prey consumption rate of $S$. takahashii is extremely lower than predators such as acarophagous ladybugs (Stethorus japonicus Kamiya) and staphylinids (Oligota kashimirica benefica Naomi). For example, the prey consumption rate for $S$. takahashii is $1 / 9$ for immatures and $1 / 13$ for female adults when compared to the respective rates of $S$. japonicus $(>120$ eggs/day for immatures and $>294$ eggs/day for female adults) (Gotoh et al., 2004). Thus, suggesting S. takahashii in synchrony with the target spider mites at the beginning of the season can have a significant impact on spider mite density and considerable potential as a biological control agent for spider mites.

The present study secondarily shows that $S$. takahashii is arrhenotokous, i.e., unfertilized haploid eggs develop into males, whereas fertilized diploid eggs give rise to females, as has been reported in other predatory thrips (Lewis, 1973). The sex ratio is female-biased, ranging from 0.758 to 0.803 (Table 4). Two other arrhenotokous species are $S$. longicornis Priesner with a female ratio of 0.753 (Sengonca and Weigand, 1988) and S. sexmaculatus with a female ratio of 0.89 (Gilstrap and Oatman, 1976) or 0.67 (Coville and Allen, 1977). Thus, the sex ratio of $S$. takahashii is similar to that of other predatory species.

Sengonca and Weigand (1988) reported that $S$. longicornis enters diapause as an adult. The overwintering stage and diapause characteristics of $S$. takahashii are unknown and need to be clarified, because the total effective temperatures above $11.7^{\circ} \mathrm{C}$ (the lower threshold temperature) in October and November exceeded or were close to the 
thermal constant (204.1 DD) during the period from 1993 to 2002 in Ibaraki. If S. takahashii enters diapause in response to the short-day length in autumn, the number of generations estimated from the total effective temperature (May-November) would decrease and diapause may reduce the effectiveness of $S$. takahashii as a biocontrol agent for spider mites during the short-day periods even in greenhouses.

\section{ACKNOWLEDGEMENTS}

We are indebted to K. Yamamura for statistical advice and Kazuya Arai and Kazushi Watanabe for their kind assistance during this study. This work was supported in part by a Grantin-Aid (Development of Innovative Technologies for Sustainable Agriculture) from the Ministry of Agriculture, Forestry and Fisheries of Japan.

\section{REFERENCES}

Birch, L. C. (1948) The intrinsic rate of natural increase of an insect population. J. Anim. Ecol. 17: 15-26.

Broufas, G. D. and D. S. Koveos (2000) Effect of different pollens on development, survivorship and reproduction of Euseius finlandicus (Acari: Phytoseiidae). Environ. Entomol. 29: 743-749.

Campbell, A., B. D. Frazer, N. Gilbert, A. P. Gutierrez and M. Mackauer (1974) Temperature requirements of some aphids and their parasites. J. Appl. Ecol. 11: 431-438.

Chazeau, J. (1985) Predaceous insects. In Spider Mites: Their Biology, Natural Enemies and Control. Vol. 1B (W. Helle and M. W. Sabelis eds.). Elsevier, Amsterdam, pp. 211-246.

Coville, P. L. and W. W. Allen (1977) Life table and feeding habits of Scolothrips sexmaculatus (Thysanoptera: Thripidae). Ann. Entomol. Soc. Am. 70: 11-16.

Cranham, J. E. and W. Helle (1985) Pesticide resistance in Tetranychidae. In Spider Mites: Their Biology, Natural Enemies and Control. Vol. 1B (W. Helle and M. W. Sabelis eds.). Elsevier, Amsterdam, pp. 405-421.

Georghiou, G. P. (1990) Overview of insecticide resistance. In Managing Resistance to Agrochemicals (M. B. Green, H. M. LeBaron and W. K. Moberg eds.). American Chemical Society Symposium Series 421. American Chemical Society, Washington, D. C., pp. 18-41.

Gilstrap, F. E. (1995) Six-spotted thrips: a gift from nature that controls spider mites. In Thrips Biology and Management (B. L. Parker, M. Skinner and T. Lewis eds.). Plenum Press, New York, pp. 305-316.

Gilstrap, F. E. and E. R. Oatman (1976) The bionomics of Scolothrips sexmaculatus (Pergande) (Thysanoptera: Thripidae), an insect predator of spider mites. Hilgardia 44: $27-59$.

Gotoh, T. (1986) Life-history parameters of the hawthorn spider mite, Tetranychus viennensis Zacher (Acarina: Tetranychidae), on deciduous oak. Appl. Entomol. Zool. 21: 389-393.
Gotoh, T. and K. Gomi (2000) Population dynamics of Tetranychus kanzawai (Acari: Tetranychidae) on hydrangea. Exp. Appl. Acarol. 24: 337-350.

Gotoh, T., M. Nozawa and K. Yamaguchi (2004) Prey consumption and functional response of three acarophagous species to eggs of the two-spotted spider mite in the laboratory. Appl. Entomol. Zool. 39: 97-105.

Kishimoto, H. (2002) Species composition and seasonal occurrence of spider mites (Acari: Tetranychidae) and their predators in Japanese pear orchards with different agrochemical spraying programs. Appl. Entomol. Zool. 37: 603-615.

Lewis, T. (1973) Thrips: Their Biology, Ecology and Economic Importance. Academic Press, London. 349 pp.

Lopez-Arroyo, J. I., C. A. Tauber and M. J. Tauber (1999) Comparative life histories of the predators Ceraeochrysa cincta, C. cubana, and C. smithi (Neuroptera: Chrysopidae). Ann. Entomol. Soc. Am. 92: 208-217.

McMurtry, J. A. and B. A. Croft (1997) Life-styles of phytoseiid mites and their roles in biological control. Annu. Rev. Entomol. 42: 291-321.

Meyer, J. S., C. G. Ingersoll, L. L. McDonald and M. S. Boyce (1986) Estimating uncertainty in population growth rates: Jackknife vs. Bootstrap techniques. Ecology 67: 1156-1166.

Miyazaki, M. and I. Kudo (1988) Bibliography and host plant catalogue of Thysanoptera of Japan. Misc. Publ. Natl. Inst. Agro-Environ. Sci. 3: 1-246 (in Japanese).

Nagata, Y. and M. Yoshida (1997) Multiple Comparison Procedures. Scientist Co., Ltd., Tokyo. 187 pp. (in Japanese).

Nakagawa, T. (1993) Studies on the seasonal occurrence and predatory activity of the predators of Kanzawa spider mite, Tetranychus kanzawai Kishida in tea fields. Bull. Saga Pref. Tea Exp. Stn. 1: 1-40 (in Japanese with English summary).

Oatman, E. R. (1970) Integration of Phytoseiulus persimilis with native predators for control of the two-spotted spider mite on rhubarb. J. Econ. Entomol. 63: 1177-1180.

Oatman, E. R. and J. A. McMurtry (1966) Biological control of the two-spotted spider mite on strawberry in southern California. J. Econ. Entomol. 59: 433-439.

Priesner, H. (1950) Studies on the genus Scolothrips. Bull. Soc. Fouad Ier Entomol. 34: 39-68.

Rice, R. E. and R. A. Jones (1972) Experimental miticides on European red and Pacific mites. Calif. Agr. 26: 12-13.

Roy, M., J. Brodeur and C. Cloutier (2003) Effect of temperature on intrinsic rates of natural increase $\left(r_{\mathrm{m}}\right)$ of a coccinellid and its spider mite prey. BioControl 48: 57-72.

Sabelis, M. W. (1985a) Reproductive strategies. In Spider Mites: Their Biology, Natural Enemies and Control. Vol. 1A (W. Helle and M. W. Sabelis eds.). Elsevier, Amsterdam, pp. 265-278.

Sabelis, M. W. (1985b) Capacity for population increase. In Spider Mites: Their Biology, Natural Enemies and Control. Vol. 1B (W. Helle and M. W. Sabelis eds.). Elsevier, Amsterdam, pp. 35-41.

Sabelis, M. W. (1991) Life-history evolution of spider mites. 
In The Acari. Reproduction, Development and Life-History Strategies (R. Schuster and P. W. Murphy eds.). Chapman and Hall, London, pp. 23-49.

Sengonca, C. and S. Weigand (1988) Biology of the predatory thrips, Scolothrips longicornis Priesner (Thysanoptera: Thripidae). Acta Phytopathol. Entomol. Hungarica 23: 343-349.

Sokal, R. R. and F. J. Rohlf (1995) Biometry. 3rd ed. W. H. Freeman and Company, New York. 887 pp.
SPSS (2002) SPSS 11.5J Brief Guide. SPSS Inc., Tokyo. 160 pp. (in Japanese).

Yamamura, K. (2002) Transformation formulae for performing correct ANOVA. Plant Protect. 56: 436-441 (in Japanese).

Yamasaki, Y., K. Yoshioka and F. Takeuchi (1983) Bionomics and predation of Scolothrips sp. Proc. Assoc. Pl. Prot. Shikoku 18: 83-86 (in Japanese). 